\title{
Neuropsychiatric lupus in children
}

\author{
P Costa Reis ${ }^{1,2^{*}}$, S Nativ ${ }^{2}$, J Isgro ${ }^{2}$, C Yildirim-Toruner ${ }^{2}$, L Imundo ${ }^{2}$, A Eichenfield ${ }^{2}$ \\ From 18th Pediatric Rheumatology European Society (PReS) Congress \\ Bruges, Belgium. 14-18 September 2011
}

\section{Background}

Neuropsychiatric manifestations (NPSLE) are common in children with lupus, and are reported to be associated with worse prognosis.

\section{Aim}

To describe the clinical characteristics of children with NPSLE, including co-morbidities, damage, and mortality.

\section{Methods}

Retrospective chart review of the clinical, laboratory, and radiographic features of SLE patients diagnosed before the age of 18 and followed at MSCHONY/CUMC in 2007-2009. Disease activity (SLEDAI) at diagnosis, occurrence of major infections, and Systemic Lupus International Collaborating Clinics Damage Index (SLICC) were evaluated.

NPSLE was defined according to American College of Rheumatology criteria.

SPSS 17.0 was used for statistical analysis.

\section{Results}

There were 120 children with SLE followed during the study period: 93 female (77.5\%, M:F 3.4:1); 61 Hispanic (50.8\%) and 34 African-American (28.3\%).

NPSLE affected 15 children (12.5\%). Cognitive dysfunction was the most common manifestation, followed by significant headache, seizures, psychosis, and focal neurologic signs. NPSLE was diagnosed in the first year in 10/15 patients (67\%). Abnormalities of brain magnetic resonance imaging were encountered in 10 patients (67\%).

Children with NPSLE had a significantly greater number of co-morbidities (end-stage renal disease, thrombocytopenia, and pancreatitis) than unaffected children with SLE $(\mathrm{p}<0.05)$. NPSLE was associated with a higher

\footnotetext{
* Correspondence: pcr.patricia@gmail.com

${ }^{1}$ Department of Pediatrics, Santa Maria Hospital, Lisbon, Portugal
}

Full list of author information is available at the end of the article
SLEDAI at diagnosis and the presence of anti-Smith antibodies $(\mathrm{p}<0.05)$.

All patients received high-dose corticosteroid and cyclophosphamide. NPSLE was associated with the occurrence of major infections, as well as a higher SLICC damage index, and mortality $(\mathrm{p}<0.05)$.

\section{Conclusions}

In this cohort NPSLE was associated with co-morbidities, major infections, and higher damage scores.

\section{Author details}

'Department of Pediatrics, Santa Maria Hospital, Lisbon, Portugal. ${ }^{2}$ Division of Rheumatology, Morgan Stanley Children's Hospital of New York-Presbyterian, Columbia University Medical Center (MSCHONY/CUMC), New York, USA.

Published: 14 September 2011

doi:10.1186/1546-0096-9-S1-P264

Cite this article as: Costa Reis et al: Neuropsychiatric lupus in children.

Pediatric Rheumatology 2011 9(Suppl 1):P264

\section{Submit your next manuscript to BioMed Central and take full advantage of: \\ - Convenient online submission \\ - Thorough peer review \\ - No space constraints or color figure charges \\ - Immediate publication on acceptance \\ - Inclusion in PubMed, CAS, Scopus and Google Scholar \\ - Research which is freely available for redistribution \\ Submit your manuscript at www.biomedcentral.com/submit}

